\title{
The Birth of the Poetess from the Spirit of the Avant-Garde: Else Lasker-Schüler's Die Nächte Tino von Bagdads
}

\author{
Vivian Liska
}

Else Lasker-Schüler's Die Nächte Tino von Bagdads (The Nights of Tino from Baghdad) is an iridescent work, combining prose and poetry, the sublime and the grotesque, and the autobiographical and the fantastic. Critics have often regarded it as an immature early work. One of the first doctoral theses on the poetess remarked that one could indeed "write a commentary on the Nächte as on Faust," but that "such a commentary would be unnecessary for literary studies" (Goldstein 12). ${ }^{1}$ What is considered "necessary" changes with the times, however, and already implies an interpretation: whereas the postwar period "needed" the restorative eternalizing of the poetess as a conciliatory figure of redemption, the seventies demanded the debunking of this mystification, and the eighties required a reading of her works as an example of feminist writing. Currently, as context-oriented cultural studies presents a challenge to the close study of literary texts, it is timely to see her work as a display of innovative poetics in which the power of literature unfolds its critical and creative potential. In this perspective, the Nächte, in which a self-reflexive writing style meets a performative autopoiesis, proves to be an early manifestation of the avant-garde that is as subversive of aesthetic conventions as it is selfcritical of the avant-garde's own revolutionary confidence. The work

${ }^{1}$ All translations into English are my own unless otherwise indicated. 
combines formal traits of experimental writing with characteristic themes of the literary avant-garde, most prominently, the role of the artist at the threshold between the old and the new world. Conspicuous in this convergence is Lasker-Schüler's ambivalent relationship to the "will to pathos" (see Zweig) so widespread in expressionism-the most German of all avant-garde movements. She complements her ambivalence on the level of content, with a simultaneous poetic selfempowerment and rejection of claims to sovereignty, hierarchy, and mastery.

Lasker-Schüler's Nächte is directed against a repressive patriarchal world, which they oppose through an anarchic and destructive act of writing. The book can be read, in this sense, as the performance of her own birth as a poetess: the persona of Tino conveys LaskerSchüler's own vocation to this apocalyptic act of writing, which the Nächte simultaneously enacts and reflects. The Nächte thus carries out the tabula rasa gesture of the avant-garde without, however, filling the newly created empty space with heroic evocations of a new power. Instead, the Nächte offers the radical idea of the "new human being" ("Neuen Menschen"), whose dangers it reveals and repels. Die Nächte Tino von Bagdads can thus be seen as an experimental artistic program and a rebellious self-project on the part of the poetess, who leaves the restrictive house of the pater familias and, as a mischievous poeta vates, declares war on the bourgeois order.

A claim to the sublime undoubtedly inheres in the poetess's selfpresentation as a chosen figure of redemption whose own awakening is destined to bring cosmic renewal to completion. Aspects of the mischievous and the grotesque, however, subvert the attendant arrogance of this "grandiose attempt" at messianic self-invocation and the "aristocratism of wholeness and strength" (Bänsch 212). They manifest themselves in the playful, at times self-ironic poetic consciousness of this mission and in the unorthodox adaptation of archaic forces to effect the renewal of a declining culture. On the level of content, they extend from explicit self-presentations as the Other of the established cultural order to the suspension of the demarcation between the private and the cosmic, the sacred and the profane, reality and fiction, up to resistance and mutiny against the preeminence of the paternal world and its heirs. This rebellion finds its formal expression in the simultaneity of the "high" and "low" that juxtaposes and comingles a lyrical-hymnal and a grotesque poetic voice or suggestive elliptical gestures that point both to the "occult" (Bänsch 213), a mysterious unsayable, and to poetic quackery. Other such expressions include 
playing with autobiographical references and alluding critically to contemporary issues; an excessive imagism, which, in the confusion of temporal and spatial orders, still eludes concrete imagination; the splitting of the subject, and the discontinuity of the plot. The text of the Nächte contains elements of the allegorical and the parabolic, invoking themes from myths, fairy tales, and the Bible, whose didactic claim is, however, withdrawn through surreal scenes and caricatured exaggerations.

\section{The Nächte as Avant-Garde Arabesque}

In its first version, which was printed in an edition for bibliophiles, Die Nächte Tino von Bagdads consists of nineteen short prose texts and nine poems. ${ }^{2}$ A poem at the opening and another at the end create the impression of a narrative framework. In between lie heterogeneous prose texts, lyrical monologues and poems, grotesques, fantastic fairy tales, quasi-epistolary "reports," and episodic tales in Oriental disguise. This heterogeneity imparts to the Nächte the character of an arabesque, such as was poetically created, conceptualized, and celebrated by the Schlegel brothers. The Oriental milieu supports this determination of genre: the reference to abstract ornaments of Arabian origin in the word "arabesque" implies an anticlassical and antimimetic conception of art developed in romanticism and sharpened by the avant-garde. This genre finds a paradigmatic expression in Lasker-Schüler's Nächte. The Oriental background signifies more than a colorful stage setting. ${ }^{3}$ Neither an alleged reproduction of reality nor merely an adoption of the contemporary exotic fashion, Lasker-Schüler's Orient springs from an antibourgeois, anarchic impulse, which-in accordance with the genre of the arabesque-seeks to obfuscate what is familiar and uniquely personal by attiring it in foreign garb.

Arabesques are abstract, counterindividualizing motifs, as can be discerned in the manifold rejection of illustrative representation, especially in the formalization of figures in the Nächte. Tino, the main figure, is the alter ego of the poetess, who counters the two types of male figures. The latter take on various forms: young, seductive but weak lovers, who are the sons of oppressive, violent patriarchs.

\footnotetext{
${ }^{2}$ See the appendix to Lasker-Schüler, Gesammelte Werke, vol. 4, 397-404, on differences between the first edition and later editions. A section in verse beginning with "Deine Schlankheit [...]" (Your slimness) is added to the prose text "Der Magier" (The Magician), but it does not constitute an independent poem, as can be seen in the first edition.

${ }^{3}$ On the Orient and its meaning in Else Lasker-Schüler's work, see, among others, Hedgepeth; Sprengel; and Kirschnick.
} 
The powerful paternal figures-Oriental dignitaries—antagonistically counterpose the beautiful male youths and, in a more complex way, Tino herself. On the one hand, the male figures appear as differing formal manifestations of one and the same instance. Tino, on the other hand, adopts changing personal forms that undermine the presumed integral persona of the omniscient narrator and the conventional uniform distance between the author, the narrative instance, and the character. Except for four texts, all the poems, lyrical monologues, and stories are written in the first person. Three of the four other texts are in the third person and tell the story of "Tino" or the "Princess of Baghdad." The last story in the book, "Der Dichter von Irsahab" ("The Poet of Irsahab"), which I shall discuss here, contains no obvious reference to the female main figure. The protagonist of this story, called "Grammaton"-Greek for "letter"-is the narrative "I" that both holds the Nächte together and disjoints them, "abstracts" itself, and disappears finally into its own text.

The Nächte narrates its own genesis. They are simultaneously the reactualization, the process, and the outcome of overcoming a speechlessness based on repression and disappointment. The book begins with the awakening of an expressive force that dissolves limits, with a healing of the mouth and the lips, which then tell the tale of a painful and secret experience of love. Autobiographically tinted and bearing the traces of Lasker-Schüler's departure from her bourgeois origins and irruption into the bohemian milieu of Berlin, the narrative reenacts in several tales the termination of a forbidden love relationship, for which a cruel and violent paternal figure and, to a lesser extent, the infidelity of a corruptible young lover are responsible. The events of this love story and its cessation due to the authoritarian father and the weakness of the sons are retold with the use of varying narrative perspectives and techniques: fragmentarily, lyrically, as a closed tale, or in a grotesque context. Tino's self-assertion as a poetess emerges from this experience. She takes over the inheritance and assumes the position of the weak "son," who emerges as the loser from the power struggle with the father figure. The female protagonist enacts a ludic appropriation of the patriarchal position of power while rejecting its authoritarian and repressive premises. The constellation of father, son, and rebellious poetess intensifies in two stories at the end of the book. In "Der Sohn der Lîlame" ("Lîlame’s Son”), Lasker-Schüler attempts the "transference of art into the practice of life," which Peter Bürger describes as the key characteristic of the avant-garde (72). Moreover, "Der Sohn der Lîlame" sets out a vision of the poetic vocation and of 
the danger of betraying it by seeking to please a philistine public. "Der Dichter von Irsahab" narrates and enacts warding off this danger and takes the provocation of the bourgeoisie to the extreme by staging the equally grotesque and cruel vision of a patricide. In both texts, an insurgent, iconoclastic poetry employs techniques of avant-garde art to rebel against a repressive order.

\section{Poetic Vocation as Provocation: "Der Sohn der Lîlame"}

"Der Sohn der Lîlame" is a grotesque parable that counterposes the true sublimity of the poète maudit with the arrogance of the artist who succumbs to the temptation of pleasing his audience. It can be read as a warning against the craving for fame of the poet who claims the status of a redemptive figure while still pandering to the public. The protagonists are Tino, the princess of Bagdad, and her cousin Mehmed, the son of the grand vizier. Everyone mocks Mehmed because of his unusual appearance until Tino reveals his particular gift to him, whereupon his greatness literally goes to his head to such an extent that he panders to the public flattery and betrays his vocation.

Mehmed is born with blue hair - a sign of his election and thus both of the affliction of being different and of heavenly illumination. The heavenly blue that his hair mirrors, does not, however, come from above, the conventional source of the sublime, but derives from the traveling vagabonds who perform their tricks beneath his pregnant mother's window. Mehmed's mother becomes melancholy because of her son's blue hair, and his father seeks to eliminate this sign of his difference. Mehmed is angry at first because his blue hair makes him an object of mockery. When he becomes older, however, he uses his power as a son of the grand vizier to take revenge on the mockers. As punishment, he forces them "to again behave as unseemly as they were guilty of doing before him on the streets of Constantinople" ("sich noch einmal so ungebührlich zu gebärden, wie sie sichs vor ihm auf den Strassen Konstantinopels haben zu Schulden kommen lassen"; Werke und Briefe 3.1: 92). He thus has his victims file past him in mimicry of their own "unseemly" actions. This "punishment" can be read self-reflexively as an allegory of satirical grotesques, but the person who brings it about, Mehmed, is himself an object of satire.

This critical grotesque satirizes a utopia in which the poet attains social recognition, and it warns against the poet's desire to please. Mehmed's punishment-a spectacle that "disfigures" the perpetrators through repetition and decontextualization-has a momentary 
effect: they revere him and ascribe magical powers to him. Mehmed cannot reconcile himself, however, to his blue hair: he "was angry with the world. Yet he loved it so much that he began to whiten his extraordinary hair with liquid chalk" ("war der Welt böse. Doch weil er sie so liebte, begann er seine aussergewöhnlichen Haare mit flüssigem Kalk zu weissen"; 93). These sentences evoke verses, although in a completely different tone, in Lasker-Schüler's poem "Mein stilles Lied" ("My Silent Song"), which she composed in 1905 at precisely the time when she also wrote the Nächte.

[...]

Meine Lieder trugen des Sommers Bläue

Und kehrten düster heim.

Verhöhnt habt ihr mir meine Lippe

Und redet mit ihr.

Doch ich griff nach euern Händen,

Denn meine Liebe ist ein Kind und wollte spielen.

$[\ldots]$

Aber meine Blicke blieben rückwärts gerichtet

Meiner Seele zu.

Arm bin ich geworden

Von eurer bettelnden Wohltat.

[...]

Und ich will euch noch mehr sagen,

Bevor es finster wird zwischen uns.

[...]

Und ich artete mich nach euch,

Der Sehnsucht nach dem Menschen wegen.

Ich riß die ewigen Blicke von meinen Augen,

Das siegende Licht von meinen Lippen-

Weißt du einen schwereren Gefangenen,

Einen böseren Zauberer, denn ich.

Und meine Arme, die sich heben wollen,

Sinken ......

(Werke und Briefe 1.1: 95-96)

The poem proceeds from accusing those who mock the speaking "I" to accusing the speaker himself of "becoming like" such people, of 
adapting and conforming to them. This warning to the poet (and to the narrative "I") not to follow the wishes and expectations of the public conforms to a romantic and avant-garde conception of the poetic vocation. The poet should refrain from betraying her "soul" by seeking recognition and then recoiling from the contempt shown to her/his unusual "lips," that is, to verses that do not correspond to conventional communication. The public derides this "lip" and simultaneously "speaks with it," mimicking its words and rendering it risible. "Der Sohn der Lîlame" redirects this derision toward the poet's adversaries by distorting, contorting, and deriding their words. The self-castigation in "Mein stilles Lied" warns the poet to withstand the temptation of fawning. The chalk-white-haired Mehmed, who is unable to bear the affliction of the poète maudit, betrays "the treasure" entrusted to him, "let us call it grace" ("unseres anvertrauten Schatzes, nennen wir es Begnadigung”), as Lasker-Schüler states in her polemical and programmatic text "Ich räume auf!" ("I'm Cleaning Up!"; Werke und Briefe 4.1: 57). The satirical form of the grotesque and the origin of Mehmed's "grace" among the street artists undermines the romanticizing kitsch latent in the conception of the poet as divine mouthpiece. This early short-prose work, which simultaneously invokes and subverts the notion of the poet as prophet and visionary, is perhaps her most successful effort to present the subtlety of avant-garde poetics.

Whereas the poem "Mein stilles Lied" illustrates, in dichotomous ways, the conflict between the conformist poet seeking recognition and the authentic poet who exposes herself to derision and mockery, the tale "Der Sohn der Lîlame" splits the poet's persona into a series of mirror images and Doppelgänger. At the "Lake of Mirrors" ("Spiegelsee"; Werke und Briefe 3.1: 93) Tino meets Mehmed, and their encounter becomes a revelation for both. Mehmed is Tino's male alter ego, which sheds an ironic light on the poet's tendency to self-mystification. Lasker-Schüler's own conception of the poet's refractory independence is also contained in Tino's sadness at Mehmed's betrayal. Mehmed, for his part, stands guilty of susceptibility to bribery in his confrontation with his authentic Doppelgänger Tino.

Tino unmasks Mehmed, who at first wants to hide and deny his particularity. Revealing to Mehmed his image in the water as he sits "on the edge of the Lake of Mirrors" ("am Rand des Spiegelsees"; 93), Tino explains his exceptionality, his gift, to him. Mehmed, who until this point has been ashamed of his blue hair, narcissistically experiences the revelation of his own greatness. He immediately falls in love with his own countenance and advances toward his fate. In a series of 
exaggerated images and metaphors, which in their excessiveness are in no way inferior to Mehmed's delusions of grandeur, Tino's cousin develops into a grotesque monster.

[U]nd eines Abends am Spiegelsee offenbarte er mir, ihn beseele die tiefe Erkenntnis, er sei tatsächlich ein Weiser und grösser als alle seine Nebenmenschen, als Mond und Sterne. [. . . ] Aus verschiedenen Ländern lässt er Geometer kommen, welche die Höhe der Granitsäulen feststellen sollen, auf denen das Dach seines Palastes ruht. Er geht Wetten ein, natürlich gewinnt er immer. Er ist ja beträchtlich grösser als die steinernen Träger. Und die Pyramide jenseits des Ufers hat er selbst mit Klötzen aus den Baukästen der Haremskinder aufgebaut. Und die mächtige Moscheekuppel war ein Punkt gegen seinen Kopf. (93-94)

In the ironic turn of these lines, which begin with indirect speech and then adopt Mehmed's image of himself as a quasi-realistic description, his self-aggrandizement assumes a grotesque dimension. The irony is created by the discrepancy between the excess of these images and the self-evident way in which the narrative persona adopts Mehmed's selfimage ("he is, indeed, considerably larger", "naturally, he always wins"). Tino's sadness at Mehmed's behavior derives from her conception of poetic election, which represents the antipode of Mehmed's delusions of grandeur. The grotesque dimensions that Mehmed's head assume symbolize his inflated self-esteem and thus realize the dark side of poetic withdrawal into solipsistic subjectivity. The image of the huge head is a frequent topos in expressionist prose. It literally embodies what Hartmut Geerken describes as a characteristic of expressionism: "The poet (or the persona created by the poet) withdraws into his skull. On one's own with the convolutions of one's brain, one has the most encompassing view. Skulls expand" (15).

The last scene of the story reveals the consequences of Mehmed's reprehensible betrayal of the artist's calling. His unworthiness comes to the fore in a confrontation with another creature of an even greater magnitude, the "elephantinehugemonster Goliathofoles" ("Elefantenriesenmonstrum Goliathofoles"; Werke und Briefe 3.1: 94), who resides in the Imperial City of the Germans (probably Berlin's Tiergarten). Goliathofoles is truly enormous: "To report conscientiously, snow lay on his head" ("[U]m gewissenhaft zu berichten: auf seinem Kopf lag Schnee"; 94). Goliathofoles, however, in contrast to Mehmed, possesses true grandeur. He proudly refuses to entertain the public, "despite the many sugar cones" ("trotz der vielen Zuckerhüte") offered to him, while Mehmed loses all dignity by trying in vain, using all sorts of enticements, to get the elephant to display his tricks: 
Mit zugespitzten Lippen, girrende Tönen flötend, versuchte er das unfolgsame Riesentier zu ermutigen. Biskuitkrümel warf er in sein höhlenaufgesperrtes Mäulchen. Er duckte sich immer kleiner, damit Goliathofoles auch den aufmunternden Trommelwirbel seiner Hände auf dem Gesäss eines seiner Diener vernehmen könne. "Gutes Kiehnd, gutes Kiehnd . . ......!"

Einen so köstlichen Prinzen hat das Publikum in seiner Hauptstadt noch nicht empfangen. Mir aber rannen schmerzende Tränen über das Herz . . . . . . . (95)

Goliathofoles rejects bribes, resisting the public's enticements. His pride is the resistance of the avant-garde artist and the poète maudit who refuse to conform. Mehmed-who hides his blue hair with cheap chalk and, as "Mein stilles Lied" has it, "molds" himself according to the people ("ich artete mich nach euch, / Der Sehnsucht nach dem Menschen wegen"; Werke und Briefe 1.1: 96)-becomes at the end "poor through your [the spectators'] begging benefaction" (“[a] rm [. . .] [v] on eurer bettelnden Wohltat"; 95), through their enticing flattery when they address Mehmed: "Good child, good child" ("Gutes Kiehnd, gutes Kiehnd . . . . . . . "). Not only does he become the "plaything" ("Schossspielzeug"; Werke und Briefe 3.1: 87) of the bourgeois, but he himself becomes a philistine. Now extremely small, he finally drums "on the posterior of one of his servants" ("auf dem Gesäss eines seiner Diener") in order to get the elephant to dance. Here, too, through taking a metaphor literally, the grotesque image emerges of the bourgeois philistine who wants to buy art on the backs of those who are subordinated and oppressed.

The gesture of resignation in the last verse of "Mein stilles Lied" corresponds to that of the poetess weeping over Mehmed at the end of the story.4 "Der Sohn der Lîlame" contains in grotesque disguise and miniature concentration a core proposition of the poetics latent in romanticism that came to fruition in the avant-garde and reached

\footnotetext{
${ }^{4}$ The inner conflicts expressed in this story and in "Mein stilles Lied" concerning the avant-garde artist's ambivalent position between the artistic ideal and material necessity, contempt for philistinism and the desire for recognition, also appear in a letter by Lasker-Schüler to Fritz Stahl: "I'll soon leave Berlin to seek my fortune. I've taken a job (solely for mat. [erial] reasons) in the orient. exhibition in Brussels. Since I spoke in Dresden at the lit. society, I've been feeling very low, Mr. Stahl. In front of 490 café creatures and 10 philistines and 3 grubs. I'd like to move from art to the work of art-but I'm very sad" ("Ich gehe bald fort von Berlin, mein Glück suchen. Ich nahm ein Engagement an [rein aus mater. Gründen] in der orient. Ausstellung in Brüssel. Seitdem ich in Dresden sprach in der lit. Gesellschaft bin ich fertig, Herr Stahl. Vor 490 Caféblasen und 10 Philistern und 3 Larven. Ich möchte es von der Kunst zum Kunstwerk bringen-aber ich bin sehr traurig; Lasker-Schüler," Wo ist unser buntes Theben 29.)
} 
its apogee in Benjamin's well-known dictum: "Nowhere does the consideration of the recipient prove productive for a work of art or an art form [...]. For no poem is for the reader, no picture for the viewer, no symphony for those who listen to it" ("Aufgabe des Übersetzers" 50). Just as with Lasker-Schüler, Benjamin's conception of the destiny of the work of art has a certain religious dimension. He sees in it-as in language in general—a form of naming in which "the spiritual essence of man communicates itself to God" ("Über Sprache überhaupt" 13). Lasker-Schüler speaks in "Mein stilles Lied" of turning back toward one's own soul and calls art in Mein Herz a "speaking to God" ("Reden mit Gott"; Gesammelte Werke 2: 46). ${ }^{5}$ They share, above all, the anti-bourgeois affectation of the avant-garde poet's refusal to regard art as a product of consumption for the Bildungsbürger.

The grotesque form taken by Mehmed's betrayal follows from and echoes other stories in the Nächte that lament the weakness, the lack of dignity, and the infidelity of the beautiful youth, this son of a power holder. It redeems Tino's contempt for Mehmed and becomes an element of her poetic self-assertion. She appoints herself to be a new poetess in his place and a poetess of the new; she accedes to the inheritance of the palace from which she had formerly been excluded. First, however, the father must die. This takes place in "Der Dichter von Irsahab," the prose text that immediately follows "Der Sohn der Lîlame."

\section{Patricide as a Grotesque: "Der Dichter von Irsahab"}

The "Dichter von Irsahab," like "Der Sohn der Lîlame," is a grotesque, explicitly characterized as such in the subtitle in the original manuscript. The story performs an act of revenge on the fathers who suppress love and ban the poet, and it stages the liberating destruction of their language. In this final, long story of the Nächte, Tino, the female protagonist, has disappeared and been replaced by a figure called Grammaton, Greek for "letter." This transformation of LaskerSchüler's alter ego fulfills her vocation as a poetess: She disappears in her own text as a poetic letter.

"Methuselah was nine hundred and sixty-nine years old when he died" ("Neunhundertneunundsechzig Jahre war Methusalem alt als er starb"; Werke und Briefe 3.1: 95) are the first words of the story. The Nächte culminates here in a joyous and apocalyptic destruction of

\footnotetext{
5"Art is speaking to God" is found in Mein Herz after she mentions Nietzsche as one of the "divinely gifted."
} 
the paternal lineage as a liberating vision of salvation. The old dies; the new, combined with the immemorial, mythical, and archaic, is victorious and sings a hymn to freedom-a children's rhyme. The murderous father figure that traverses the Nächte and embodies the principles of domination, authority, and power is deposed from the throne and destroyed. The victorious rebel is Methuselah's youngest son, Grammaton. "And Grammaton was a poet" ("Und Grammaton war ein Dichter"; 96) born "under Pegasus, the new constellation" ("mit dem neuen Sternbild Pegasus"; 96). Grammaton is the letter of the new script, the actions of avant-garde poetry as mischievous subversion of the patriarch's authority.

Grammaton's emblem is Pegasus, the symbol of winged poetic inspiration. Like Mehmed, he has a blue feature, but whereas Mehmed's blue hair derives from the street artists who ply their trade below his mother's window, Grammaton has inherited his blue eyes from his father, who "was closer to the blue beyond than to the earth" ("der blauen Ferne näher war, wie der Erde”; 95). Like Mehmed, Grammaton is "graced by heaven" ("Himmelbegnadeter"). ${ }^{6} \mathrm{He}$, however, utilizes the knowledge of his election differently than Mehmed and the other youths in the book: He neither betrays love or poetry nor becomes a victim of paternal authority and appears at the end as a truly revolutionary redeemer.

The father Methuselah, his two eldest twin sons, and his youngest son Grammaton play the main roles in this story. The latter is the poet of Irsahab. Ir is Hebrew for "city"; sahab is probably a transformation of "sahib," Arabic for "Sir" or "Lord." Grammaton is a poet in the city of lords, of grand viziers and moguls, fakirs and khedives, priests and prophets, who people the Nächte and lend their names to most of the other stories. In this vision of redemption, the epoch of the fathers comes to an end. Methuselah is tired, gloomy, and sad; he embodies the dark authority of the elders, which intimidates youthful lovers and children at play. Methuselah dies, leaving the blue beyond of the sublime spirit and returning to the maternal womb of the earth, accompanied by the lullabies of his wet-nurse, who also dies that very day. The paternal principle of old authority and the maternal principal of reconciliatory consolation thus die at the same time and reunite in eternal peace.

Methuselah leaves behind, however, as the last poem of the Nächte, "Das Lied meines Lebens" ("The Song of My Life"). It tells of "sib-

\footnotetext{
${ }^{6}$ Lasker-Schüler uses this concept in Mein Herz to designate some poets, thinkers, and "creators of religions" whom she admires (Gesammelte Werke 2: 46).
} 
lings who fought with each other to the death" ("Geschwister, die sich tötlich stritten"; 97): the elder calculating, haggling, bourgeois twin brothers and Grammaton, the poet. The elder brothers cheat Grammaton out of his share of the inheritance and banish him from the palace because he violates their property, the columns of the paternal house, by inscribing his poetry onto them: "And he thought, I can mint my golden thoughts only in stars and signs on the pillar supporting the roof of my father's house" ("Und er dachte, ich kann meine goldenen Gedanken nur prägen in Sternen und Zeichen in die Säule, die das Dach meines Vaterhauses trägt"; 96). This pillar, both in its verticality and height and in its function as a support of the hierarchical authority of the paternal house, can be understood as the poetic tradition, which Grammaton usurps. He writes his letters on this column because he "thought" ("dachte") at first that it was his only possibility of expression, the "temple of his art" ("Tempel seiner Kunst"; 96). But in the course of destroying his father's monument, he also destroys the medium of his own writing. After being driven out of the paternal home, Grammaton takes revenge in a biblical way:

Und sein Hass dehnt sich aus auf die Kinder und Kindeskinder und er streute kranke Saat unter sie und eines riss das andere vom Erdboden fort. Aber ebenso schnell wuchsen sie wieder auf, von Kindeskind zu Kindeskindeskind, und starb der Vater so ersetzte ihn ein Sohn in der Nacht. Und Grammaton sah ein, die ganze Stadt war mit ihm verwandt und sein Hass wuchs von Glied zu Glied und er zertrat das mutwillige Zieglein, was ihm in den Weg lief-ehe es wiederkehre einmal auf zukünftigem Sterne als irgendeines kommenden Urneffen Sohnes Sohn. Und es gelang ihm, das Geschlecht Methusalem auszurotten und das waren alle Einwohner der Stadt und selbst der Tempel der Stadt, die Säule die das Dach seines Vaterhauses trug, verschonte er nicht. (96-97)

The biblical language in the description of Grammaton's destruction of the fathers' lineage is reminiscent of God's command to Saul, King of the Jews, to wipe out the Amalekites, the enemies of Israel: "You shall not spare him, and you shall put to death man and woman, infant and sucklings, ox and sheep, camel and donkey" (David 1 Sam. 15.3). Saul did not, however, obey the divine command; he spared Agag, king of the Amalekites, and with him "the best of the sheep and the cattle, the fat ones and the young ones, everything good" (1 Sam. 15.9). Thus, Israel's enemies survived. The biblical Ammonite prophet Bilaam, however, predicted the victory over the Amalekites in a messianic oracle: "His king looms over Agag and his kingship is lifted high" (Five Books 4 Num. 24.7). Contrary to the biblical king 
Saul, Grammaton does enact Bilaam's prophecy and kills his enemies without sparing even "the willful kid that crossed his path before it may return someday on a future star" ("das mutwillige Zieglein, was ihm in den Weg lief-ehe es wiederkehre einmal auf zukünftigem Sterne"; Werke und Briefe 3.1: 96). ${ }^{7}$ The grotesque turn in the description of this savage violence is unmistakable, but it does not diminish the poet's violent vision of a destruction of the patriarchal abode.

A black raven with demonic traits incited Grammaton to carry out this apocalyptic act. Under his spell, Grammaton's "soul arose in the morning light and was filled with gold" ("Seele aufging unter Morgenleuchten und sich füllte mit Gold"; 96). The raven enables him to recognize his vocation as a rebellious redeemer, and he accepts the mission. This raven is the incarnation of "Enoch" ("Henoch"), Methuselah's father, about whom it was said that he "could no longer die". The legends surrounding the biblical Enoch indeed refer to the enigmatic declaration: "And Enoch walked with God and he was no more, for God took him" (Five Books Gen. 5.24). This is understood as Enoch's rising to heaven without actually dying. The apocryphal tradition regarded Enoch as a hero, but rabbinical circles often saw him as the embodiment of evil. In some apocryphal writings, Enoch is a messenger of God and appears as a divine scribe. ${ }^{8} \mathrm{He}$ is the hero and the author of apocalyptic writings: two of the most important apocalyptic works that announce the coming of the messiah after radical destruction are attributed to him. Analogously, Lasker-Schüler's Enoch appears as a messenger who speaks to Grammaton in a tone of warning, calls on him to revolt against the unjust brothers, and assumes the role of the demonic but liberating insurgent in the redeeming extermination of the patriarchal world.

Enoch embodies the turn to the archaic that traverses the entire Nächte and is realized in the manifold intertextual references to the Bible, myth, and antiquity. If Grammaton's poetry is envisioned in the Nächte as the inscription of the "new letter", his companion Enoch stands for the mythical-archaic dimension that accompanies the avantgarde orientation of the book. The reaching back to primeval times points to the romantic and expressionist conception of a "fallen" bourgeois society that has distanced man from his original vocation.

\footnotetext{
${ }^{7}$ Rabbinic legends explain the resurgence of Israel's enemies with the metempsychosis of the Amalekites into the form of their sheep and cattle. Grammaton's killing of "the willful kid that crossed his path before it may return someday on a future star" could be an allusion to this legend.

"Enoch [is] the righteous scribe [who] acts as the intermediary between [men] and God" (Grintz 795).
} 
Only through a messianic and revolutionary apocalypse, and in a new mythical time, can Enoch arise as a "new man" and be redeemed.

Upon Enoch's insistence, Grammaton takes revenge and extinguishes Methuselah's lineage- "and that was all the inhabitants of the city" ("und das waren alle Einwohner der Stadt"): Grammaton cleans up. His insurrection has social, religious, and aesthetic dimensions. Through a grotesque and apocalyptic destruction of the authority of the elders, he destroys the entire city with its bourgeoisie and philistines, priests and patriarchs-possibly standing for the publishers and editors whom Lasker-Schüler accuses in her pamphlet "Ich räume auf" of banning the anointed poet from the city and hindering his messianic rebellion.

The ending of the story is extant in two versions; one comes from the first edition and the other from a manuscript used as a copy for Lasker-Schüler's readings and performances. At the end of the manuscript version, Grammaton sits with Enoch "at his fireproof and indestructible writing desk" ("an seinem feuersicheren unzerstörbaren Schreibtisch”; Werke und Briefe 3.2: 90) and sings:

Was kommt dort von der Höh-

Was kommt dort von der Höh?

Was kommt dort von der ledern Höh

Zieh, zah ledern Höh

Was kommt dort von der Höh?

Es ist Methusalem

Es ist Methusalem

Der lederne Herr Herr Papa

Zieh zah Herr Papa

Papa Methusalem!! (Werke und Briefe 3.2: 90)

With the destruction of the pillar of his father's house and of art as a temple, Grammaton also turns away from the vertical, hierarchical sublime and intonates a silly children's ditty about the father who comes from on high. Grammaton thus enacts and finalizes the new letter, the revolt against the authority of the philistines and patriarchs. He becomes a redemptive figure as the herald of iconoclastic, blasphemous art. A passage in "Ich räume auf!" which appeared almost twenty years later, alludes to this children's rhyme. It uses the rhyme as a mark of recognition to show that the father who comes from on high also embodies the most sublime of all fathers-God himself. Upon the death of her friend Paula Dehmel, the wife of the artist Richard Dehmel, Lasker-Schüler writes: 
Schon auf Erden trug sie zwei Flügel und schwebte über alle Undinge. Auf dem Weg zu ihr erkannte sie mich schon: "Was kommt dort von der Höh'”- an meinem Pfeifen noch fern vom Tore .... "Das Flackerlicht von Horeb kommt." Aber heute flackere ich nicht mehr, ich brenne geliebte Spielgefährtin im Himmel, ich rauche-ein feuerspeiender Berg, ich speie glühenden Aschenregen, Unmenschen zu verschütten, aufzuräumen für mich, für Dich, für die Lebenden, für die toten Dichter, für die Dichtungen aller Ewigkeit. (Werke und Briefe 4.1: 70-71)

"The flashing light comes from Horeb": Horeb is another name for Mount Sinai where God revealed himself. In this quote, the one who flashes light from the holy mountain is none other than Lasker-Schüler herself. Her usurping of divine majesty should not, however, be read as messianic self-elevation but as the mischievous subversion of the sublime origins of biblical language and its commands, to which she alludes. Her aim here, as at the end of the story, is to get rid of the "fiends" ("Unmenschen") who ban the poet. Grammaton's destruction of the pillar that bears the roof of his father's house can, however, be understood in a further sense: as the "temple of his art," it should be understood not only as the poetic tradition but also as language as such.

Instead of ending with the children's rhyme that Grammaton sings "at his fireproof and indestructible writing desk," the first edition concludes with the words: "[A]nd he, Grammaton, sat on the tail of a stone monkey and sang: i! ü! hiii è!!/ i! ü! hiii è!!” (“[U]nd er, Grammaton, sass auf dem Schwanz eines steinernen Affen und sang: i! ü! hiii è!! / i! ü! hiii è!!”; Werke und Briefe 3.1: 97). If one can see the children's rhyme of the manuscript as the realization of Grammaton's destruction, the printed version goes a step further in the sense of an iconoclastic art. The column of Grammaton's "temple of his art" represents language as a meaningful, ordered system of communication. Destroying this support of his father's house thus applies to language itself. The nonsense of the final "verses," which can at best be construed as a wild triumphal cry, enacts the radical avant-garde's characteristic annihilation of conventional language to the bitter end.

This passage hints at the relationship of writing to language. Grammaton represents the written letter, ${ }^{9}$ which destroys the father's temple. In a later edition of the Nächte, the "tail of the stone monkey" replaces the "fireproof, indestructible writing desk" as the locus of a triumphant uprising. The monkey is primarily a "grotesque" animal that has the attributes of the mythological trickster. For the

${ }^{9}$ In Greek, $\gamma \rho \alpha \mu \mu \alpha$ refers specifically to the written letter, in contrast to the more

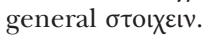


Greeks-and Grammaton is Greek-he takes the form of the Cercopes, standing for the "trickster, a cheeky mountebank", related to Hermes (Chevalier and Gheerbrant 666). As the Dictionary of Symbols explains, the Greek myth of the Cercopes (who gave their name to a genus auf African long-tailed monkeys, the Cercopithecus) illustrates "the monkey-highwayman, the cheerful rogue whose jokes disarm ill humour" (666). Sitting on the monkey's tail thus serves as the ideal setting for Grammaton's cry of jubilation, intensifying the grotesque element of the story. This reference does not explain, however, the link between the two endings of "Der Dichter von Irsahab." The seemingly arbitrary connection between the writing desk of the first version and the monkey of the second becomes clearer if one recalls that the monkey is the incarnation of the god Thoth (or Theuth), the god of writing, in Egyptian mythology. In Egyptian iconography, a bird, an ibis, sits adjacent to Thoth, an image echoed by the raven sitting in the cavities of Grammaton's shoulders. Thoth is, like Enoch, a divine scribe: He is, in Greek mythology, the one "who registers the word of Ptah, the creator God" (Derrida 101). The correlation of the monkey with Hermes takes place via the figure of Thoth, who is related to him also in his function of the incorrigible trickster:

Thoth participates frequently in plots, in perfidious operations, in usurping maneuvers directed against the king. He helps the sons to rid themselves of the father and the brothers to rid themselves of the brother after this one has become king. The god of writing thus becomes the supplicant of $\mathrm{Ra}$ [the supreme father and king], joining him and replacing him in his absence and essential departure [. . .]. (100)

These allusions enable one to trace a finely spun web of unexpected connections. Plato's Phaedrus suggests a context for locating a relationship between the Egyptian god Thoth and the Greek letter Grammaton. In the course of a discussion on the value of rhetoric (as art) versus dialectic (as philosophy), writing versus the pure truth of logos, Socrates relates the scene in which Thoth presents his invention, the art of writing, to Thamus, the king of Thebes, and the king rejects it:

At the Egyptian city of Naucratis, there was a famous old god, whose name was Theuth; the bird that is called the Ibis is sacred to him, and he was the inventor of many arts, such as arithmetic and calculation and geometry and astronomy and draughts and dice, but his great discovery was the use of letters. Now in those days the god Thamus was the king of the whole country of Egypt; and he dwelt in that great city of Upper Egypt which the Hellenes call Egyptian Thebes, and the god himself is called by them Ammon. To him came Theuth and showed his inventions, desiring that the other Egyptians 
might be allowed to have the benefit of them; he enumerated them, and Thamus enquired about their several uses, and praised some of them and censured others, as he approved or disapproved of them. It would take a long time to repeat all that Thamus said to Theuth in praise or blame of the various arts. But when they came to letters, this, said Theuth, will make the Egyptians wiser and give them better memories; it is a specific both for the memory and for the wit. Thamus replied: $\mathrm{O}$, most ingenious Theuth, the parent or inventor of an art is not always the best judge of the utility or inutility of his own inventions to the users of them. And in this instance, you who are the father of letters, from a paternal love of your own children have been led to attribute to them a quality which they cannot have; for this discovery of yours will create forgetfulness in the learners' souls, because they will not use their memories; they will trust to the external written characters and not remember of themselves. The specific which you have discovered is an aid not to memory, but to reminiscence, and you give your disciples not truth, but only the semblance of truth; they will be hearers of many things and will have learned nothing; they appear to be omniscient and will generally know nothing; they will be tiresome company, having the show of wisdom without the reality. (Phaedrus $274 \mathrm{c}-\mathrm{e}$ )

In "La pharmacie de Platon," Jacques Derrida considers this passage and elucidates the reasons for the king's rejection of letters. He interprets writing as a dangerous pharmakon because it renders the presence of the origin - the presence of the father-superfluous. Writing thus liquidates the authority of the author of the letters, usurps the father of logos, imposing itself in his place yet without appropriating his authority, thereby rendering itself vulnerable:

In Phaedrus, the god of writing is thus a subordinate figure [. . .], a wily and ingenious servant who is permitted to appear before the king of the gods [... . . Like his counterpart Hermes, he fills the role of the messenger god, the wily, ingenious, and subtle intermediary who always purloins and worms his way in. (Derrida 99)

The last words in this characterization recall Elisabeth Lenk's designation of the trickster as doubly a thief who "purloins things but who also [...] steals his way into everything” (45). In Derrida's explication, writing plays a role similar to that of the patricide Grammaton in Lasker-Schüler's story or to Lasker-Schüler's avant-garde writing itself: it constitutes a mischievous threat to the father. The god of writing cannot be assigned to a fixed place; he is, like Hermes, "rather a kind of joker, an available nonentity, a neutral card, imparting playfulness to what is at play" (Derrida 105). In the grotesque "Der Dichter von Irsahab," the ironic form of the narration contributes to the effect of play. If Grammaton, particularly in his function as a poet, appears as 
a mouthpiece for Lasker-Schüler, this figure plays with her persona: the ambivalent, mocking description of Grammaton's "noble tears" ("Edeltränen") at the loss of his inheritance and of the "willful kid," on which Grammaton stamps in his destructive fury-indeed the excess of this destruction itself - create an ironic distance, which does not invert the statement into its opposite but unsettles the omniscient perspective of the entire scene. Similarly, the biblical language of authority, which can be heard in these lines, is both invoked and undermined.

Grammaton, the letter, who sits in all its lack of respect on the tail of the stone monkey, the statue of his father Thoth, points to writing as a patricide committed by a trickster who is continually evasive, indeterminable, polyvalent, and who undermines the hierarchically exclusive truth of the omnipotent One. Grammaton, however, does not become a master of writing but remains an anarchic rebel. He anticipates the creative provocation of the avant-garde that reaches from expressionism to Dada with his nonsensical sounds, his stammering, derisive and triumphant calls to battle that are also deeply serious children's rhymes.

\section{Coda}

Lasker-Schüler's sketches of the downfall of the old order and the birth of a new world are accompanied by a lament at the futility of this enterprise. Thus, the Nächte ends on a somber note:

Das Lied meines Lebens

Sieh in mein verwandertes Gesicht ....

Tiefer beugen sich die Sterne

Sieh in mein verwandertes Gesicht.

Alle meine Blumenwege

Führen auf dunkle Gewässer,

Geschwister, die sich tötlich stritten.

Greise sind die Sterne geworden .....

Sieh in mein verwandertes Gesicht. (Werke und Briefe 3.1: 97)

The final poem of the Nächte speaks of "the stars bow more deeply," "dark waters," and "brothers and sisters who fought to death." Marked by melancholy, the poem emanates a knowledge of the impotence of its own vision. Only a faint hope remains: the challenge to the reader to share its defeat and to perceive the absence of redemption. The poem thus anticipates the failure of the avant-garde aspiration for 
renewal through the spirit of poetry. This mourning skepticism, which concludes Lasker-Schüler's Nächte, prevents her call to rebellion from slipping into pathetic and empty gestures and foresees the danger of the avant-garde nullifying itself through rivalry, complicity with the bourgeois, and its own self-aggrandizement.

University of Antwerp

\section{WORKS CITED}

Bänsch, Dieter. Else Lasker-Schüler: Zur Kritik eines etablierten Bildes. Stuttgart: Metzler, 1971.

Benjamin, Walter. "Die Aufgabe des Übersetzers." Illuminationen. Frankfurt am Main: Suhrkamp, 1977. 50-62. Print.

."Über Sprache überhaupt und über die Sprache des Menschen.” Angelus Novus. Frankfurt am Main: Suhrkamp, 1988. 9-26. Print.

Bürger, Peter. Theorie der Avantgarde. Frankfurt am Main: Suhrkamp, 1974. Print.

Chevalier, Jean, and Alain Gheerbrant, eds. A Dictionary of Symbols. Trans. John BuchananBrown. Cambridge: Blackwell, 1994. Print.

The David Story: A Translation with Commentary of 1 and 2 Samuel. Trans. and notes by Robert Alter. New York: W. W. Norton: 1999. Print.

Derrida, Jacques. La dissémination. Paris: Editions du Seuil, 1972. Print.

The Five Books of Moses: A Translation with Commentary. Trans. and notes by Robert Alter. New York: W. W. Norton, 2004. Print.

Geerken, Hartmut. Märchen des Expressionismus. Darmstadt: Agora Verlag, 1979. Print.

Goldstein, Fanny. Der expressionistische Stilwille im Werk Else Lasker-Schülers, Phil. Diss. Universität Wien, 1936. Print.

Grintz, Yehoshua M. "Enoch, Ethiopic Book of. Encyclopaedia Judaica. Ed. Cecil Roth. Vol. 6. Jerusalem: Keter, 1971. 795-97. Print.

Hedgepeth, Sonja M. "Die Flucht ins Morgenland: Zum Orientalismus im Werk Else Lasker-Schülers." Kulturelle Wechselbeziehungen im Exil—Exile across Cultures. Ed. Helmut F. Pfanner. Bonn: Bouvier, 1986. Print.

Kirschnick, Sylke. Tausend und ein Zeichen: Else Lasker-Schülers Orient und die Berliner Alltags- und Populärkultur um 1900. Würzburg: Königshausen \& Neumann, 2007. Print.

Lasker-Schüler, Else. Gesammelte Werke in acht Bänden. Ed. Friedhelm Kemp. Munich: dtv, 1986. Print.

- Werke und Briefe: Kritische Ausgabe. Ed. Norbert Oellers, Heinz Rölleke, and Itta Shedletzky. Frankfurt am Main: Jüdischer Verlag, 1996-2010. Print.

. Wo ist unser buntes Theben. Briefe II. Ed. Margarete Kupper. Munich: Kösel, 1969. Print.

Lenk, Elisabeth. Die unbewusste Gesellschaft. Munich: Matthes \& Seitz, 1983. Print.

Plato. "Phaedrus." The Dialogues of Plato. Trans. Benjamin Jowett. Vol 1. Oxford: Oxford UP, 1892. 431-489. Print.

Sprengel, Peter. "Exotismus bei Paul Scheerbart und Else Lasker-Schüler: Zur Literatur

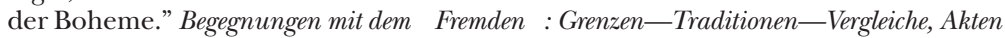
des VIII. Internationalen Germanistenkongresses Tokyo 1990. Ed. Eijiro Iwasaki. Vol. 7. Munich: iudicium, 1991. 465-75. Print.

Zweig, Stefan. "Das Neue Pathos.” Das literarische Echo 11 (1908/9): 1701-7. Print. 